\title{
Digestibility of Feeds Containing Sorghum, With and Without Tannin, for Broiler Chickens Submitted to Three Room Temperatures
}

Author(s)

Garcia RG'

Mendes $\mathrm{AA}^{2}$

Sartori JR

Paz ICLA'

Takahashi SE

Pelícia K ${ }^{1}$

Komiyama CM

Quinteiro RR'

1 Graduate Student in Animal Science of the Faculty of Veterinary Science and Animal Production, UNESP - Botucatu-SP, Brazil.

2 Full Professor of the Faculty of Veterinary Science and Animal Production, UNESP Botucatu-SP, Brazil.

\section{Mail Address}

Rodrigo Garófallo Garcia

Faculdade de Medicina Veterinária e Zootecnia UNESP - Campus de Botucatu

Fazenda Experimental Lageado, $\mathrm{s} / \mathrm{n}$

Tel.: (14) 3811-7189

18.618-000 - Botucatu, SP

E-mail: garofallo@fca.unesp.br

\section{Keywords}

Broiler chickens, digestibility, sorghum, tannin.

Research supported by FAPESP (Fundação de Amparo à Pesquisa do Estado de São Paulo).

\section{ABSTRACT}

The traditional method of total excreta collection was applied, using 30 to 40 day old male Ross 308 broiler chickens. One hundred and eight broiler chickens were used, randomly assigned to a $3 \times 3$ factorial experimental design. The room temperatures were $14{ }^{\circ} \mathrm{C}$ (cold), $25^{\circ} \mathrm{C}$ (thermoneutral) and $32{ }^{\circ} \mathrm{C}$ (hot) and the three diets were $100 \%$ maize, $100 \%$ sorghum with tannin and $100 \%$ sorghum without tannin, with four replicates of each. The digestibility coefficients for the dry matter, crude protein, crude fibre, neutral detergent fibre, acid detergent fibre, ether extract, mineral matter and nitrogen-free extract were determined. It was observed that all the digestibility coefficients were higher in the hot chamber and lower in the cold chamber, and that these values tended to be higher for maize.

\section{INTRODUCTION}

Sorghum is an important cereal, ranking fifth in world production, behind wheat, corn, rice and barley and being used for both human and animal consumption throughout the world (Gualtieri \& Rapaccini, 1990). In regions such as Asia, Africa, China, Russia and Central America, sorghum grains are mostly used for human consumption, whilst in South and North America, Europe and Australia, they are produced mostly for animal feed. Amongst the various different alternative foods, sorghum stands out as a resource capable of significantly reducing costs in poultry feeding, at a time of year when the final cost of broiler chickens is at its highest.

Despite similarities with maize with respect to the carbohydrate and protein compositions, sorghum presents a group of phenolic compounds in its structure, including tannins. All sorghum varieties contain phenolic compounds, which can influence the colour, appearance and nutritive value of the grain, and they can be divided into three groups: acidic phenolics, flavanoids and tannins. The presence of tannin reduces the nutritional value of a diet, mainly due to a decrease in the use of the protein and a reduction in the activity of digestive enzymes (Haslam, 1981). In consequence, nitrogen retention and use of the amino acids are reduced due to the reduction in protein digestibility (Mitaru et al., 1984; Mustafa \& El Zubeir, 1993; Elkin et al., 1995).

The carbohydrates are also affected by tannin, possibly due to the formation of complex compounds, which are difficult to digest (Trevino et al., 1992; Mahamood \& Smithard, 1993). The vitamins and minerals, especially those of the $B$ complex, plus iron and calcium are all affected by the presence of tannin in the diet (Bagepalli et al., 1982; Mehansho et al., 1987; Chang et al., 1993).

The first study on the determination of nutrient digestibility for poultry, was carried out by Hill \& Anderson (1958). According to Rostagno et al. 
(1977), the addition of sorghum to broiler chicken diets could present some variations in nutrient digestibility when compared to feeds formulated with a corn base. These results could vary according to the tannin content of the sorghum grain and the environmental conditions to which the birds were submitted.

According to Gomes \& Macari (2000), the tropical and sub-tropical countries present the greatest potential for the production of domestic fowl, one of the major obstacles being the hot climates in these regions. Daytime temperatures above 30 to $32{ }^{\circ} \mathrm{C}$ are considered stressful for the birds and have a negative effect on performance, reducing food ingestion. During heat stress, feed consumption decreases, the birds become slower and drink from 2 to 3 times more water, increasing the excretion of water via panting and urinating and increasing the digestibility of the diet nutrients.

Based on these considerations, the objective of this study was to evaluate the digestibility of feeds containing sorghum, with and without tannin, in broiler chickens submitted to three different room temperatures.

\section{MATERIAL \& METHODS}

The experiment was carried out in the experimental facilities of the Faculty of Veterinary Science and Animal Production of UNESP, Botucatu, Brazil, initially installed in a broiler house constructed in an east-west direction, $8 \mathrm{~m}$ wide, $40 \mathrm{~m}$ long, $3.5 \mathrm{~m}$ tall and covered with asbestos cement tiles. The broiler house was divided into $3.25 \times 1.55 \mathrm{~m}$ pens, providing an area of $5 \mathrm{~m}^{2} /$ pen. The pens were separated from each other by $40 \mathrm{~cm}$ brick walls, each being equipped with two tubular $20 \mathrm{~kg}$ capacity feeders and a pendular drinker. The sidewalls were of brick up to $40 \mathrm{~cm}$, completed with galvanised wire fencing and protected by moveable curtains. Fans were distributed so as to provide uniform ventilation for all of the pens.

Digestibility assay was carried out at the Poultry Nutrition Laboratory of the Department of Animal Nutrition and Improvement of the Faculty of Veterinary Science and Animal Production (FMVZ) UNESP - Botucatu, Brazil. The traditional method of total excreta collection was applied, using 30 to 40 day old intact male Ross 308 broiler chickens. One hundred and eight intact broiler chickens were used, randomly assigned to a $3 \times 3$ factorial experimental design. The room temperatures were $14{ }^{\circ} \mathrm{C}$ (cold),
$25{ }^{\circ} \mathrm{C}$ (thermoneutral) and $32{ }^{\circ} \mathrm{C}$ (hot) and the three diets were $100 \%$ maize, $100 \%$ sorghum with tannin and $100 \%$ sorghum without tannin, with four replicates of each. The digestibility coefficients for the dry matter, crude protein, crude fibre, neutral detergent fibre, acid detergent fibre, ether extract, mineral matter and nitrogen-free extract were determined.

The breeding system used was that traditionally used in commercial operations. During the first week automatic cup-type pressure drinkers and infantile tubular feeders were used. As from the second week, pendular drinkers and tubular feeders were used. Initially heating was by way of $250 \mathrm{~W}$ infrared lamps in each pen. Artificial lighting of the house was provided using 40W lamps in order to obtain 22 lumens per $\mathrm{m}^{2}$ thus providing 24 hours light daily throughout the whole period. Wood shaving litter, $10 \mathrm{~cm}$ deep, was used as the bedding.

The birds were vaccinated against Marek's disease in the incubator and against Newcastle's disease at 10 days of age, via the drinking water.

The birds received water and feed ad libitum. throughout the whole breeding period, which was divided into two phases: starter (1 to 21 days) and grower (22 to 35 days). The feeds were formulated according to the nutritional levels normally used commercially (Table 1).

At 30 days of age the birds were transferred to the acclimatised chambers and placed in digestibility cages. The internal temperatures of the acclimatised chambers were controlled throughout the entire period by sensors connected to a central control panel, which was monitored by a computer, which, in turn, recorded the temperature and humidity inside the chambers. An exhaustion system renewed the air within the chambers. The average temperature in the cold chamber was $14{ }^{\circ} \mathrm{C}$, that of the thermoneutral chamber $25^{\circ} \mathrm{C}$ and that of the hot chamber $32{ }^{\circ} \mathrm{C}$.

The adaptation period to the experimental diets was from 30 to 37 days and the excreta were collected from day 38 to day 40 . The excreta were removed from the collection trays every 12 hours during the three collection days. After collection the samples of excreta were frozen for later analysis. The analyses were carried out A.O.A.C. (1990) in the Laboratory of Animal Nutrition of the Faculty of Veterinary Science and Animal Production, UNESP, Botucatu, Brazil. 


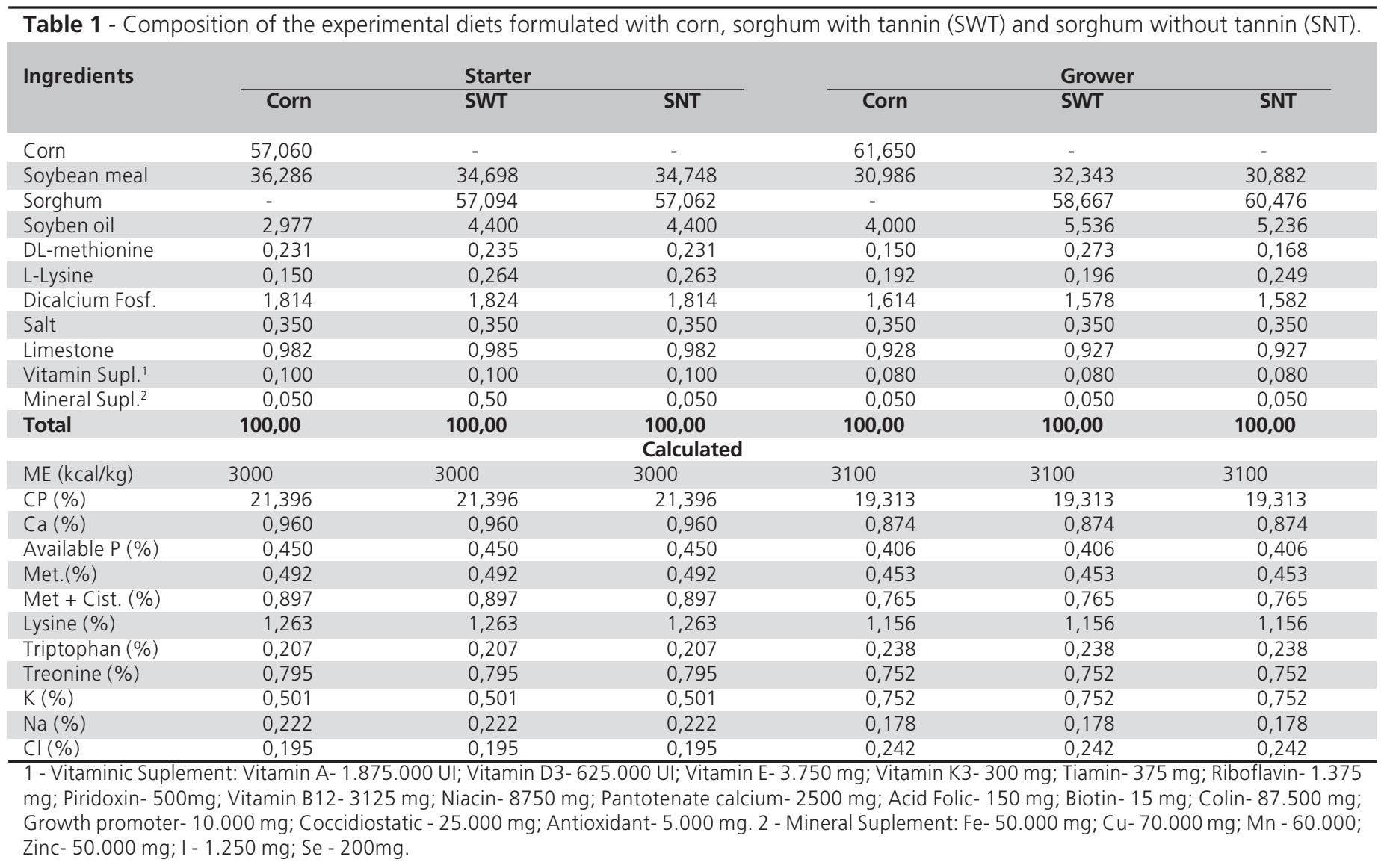

\section{RESULTS AND DISCUSSION}

Tables 2, 3, 4 and 5 shows the results for all the digestibility coefficients. For the digestibility coefficients of the dry matter, only the temperatures showed a significant effect $(p<.05)$, the highest values being observed in the hot chamber.

For the digestibility coefficients for crude protein, significant effects $(p<.05)$ were shown both for the temperatures, with the highest values being observed in the hot chamber, and for the diets, the birds fed on the maize based diets showing the highest values. There was no difference ( $p>.05)$ between the digestibility coefficients for crude protein obtained with the high tannin sorghum based diet and the values obtained with the low tannin sorghum based diet. The significant effect of the diets on the digestibility coefficients for crude protein is in agreement with the results obtained by Haslam (1981) who stated that tannin reduced the nutritional value of the diet, mainly by reducing the utilisation of the protein and the activity of the digestive enzymes. Consequently nitrogen retention and the utilisation of the amino acids were decreased due to the reduction in protein digestibility (Mitaru et al., 1984; Mustafa \& El Zubeir, 1993; Elkin et al., 1995).

Neither diets nor temperatures showed a significant effect ( $p>0.05$ ) on the digestibility of crude fibre. There was a significant effect for temperature $(p<0.05)$ on the neutral detergent fibre, the greatest values being observed in the hot chamber, there being no difference ( $p>0.05$ ) between the digestibility coefficients observed in the cold and thermoneutral chambers. Similar results were observed by Elkin et al. (1995).

The digestibility coefficients for acid detergent fibre showed a significant effect $(p<0.05)$ for temperature, the greatest values being observed in the hot chamber. There was also a significant effect $(p<0.05)$ for the diets, the highest values being observed for the birds fed on the maize based diet in agreement with the results of Elkin et al. (1995).

Neither temperature nor diet showed a significant effect ( $p>0.05$ ) on the digestibility coefficients of the ether extract. However the digestibility coefficients for mineral matter showed a significant effect $(p<0.05)$ for 
Table 2 - Digestibility coefficients ${ }^{1}$ for dry matter and crude protein determined by the digestibility assay using total excreta collection from broiler chickens fed on corn based, high tannin sorghum based (HT) and low tannin sorghum based (LT) diets and submitted to three room temperatures.

\begin{tabular}{|c|c|c|c|c|c|}
\hline & \multirow[b]{2}{*}{ Chambers } & \multicolumn{4}{|c|}{ Diets } \\
\hline & & Corn & Sorghum (HT) & Sorghum (LT) & Mean \\
\hline \multirow[t]{4}{*}{ Dry Matter } & Cold & $82.953^{2}$ & 82.995 & 82.470 & $82.806 \mathrm{~B}$ \\
\hline & Neutral & 84.894 & 83.024 & 83.983 & $83.967 \mathrm{~B}$ \\
\hline & Hot & 87.605 & 86.300 & 87.569 & 87.158 \\
\hline & Mean & 85.151 & 84.106 & 84.674 & - \\
\hline \multirow[t]{4}{*}{ Crude protein } & Cold & 76.612 & 72.976 & 72.941 & $74.176 \mathrm{~B}$ \\
\hline & Neutral & 75.322 & 74.024 & 75.770 & $75.039 \mathrm{~B}$ \\
\hline & Hot & 79.635 & 76.257 & 76.115 & $77.336 A$ \\
\hline & Mean & $77.190 \mathrm{~A}$ & $74.409 \mathrm{~B}$ & 74.942 B & - \\
\hline
\end{tabular}

1 - Values expressed on a dry weight basis. 2 - Means followed by the same small letter in the same line and means followed by the same capital letter in the same column, do not differ according to Tukey's test ( $p>0.05)$.

Table 3 - Digestibility coefficients ${ }^{1}$ for crude fibre and neutral detergent fibre (NDF) determined by the digestibility assay using total excreta collection from broiler chickens fed on corn based, high tannin sorghum based (HT) and low tannin sorghum based (LT) diets and submitted to three room temperatures.

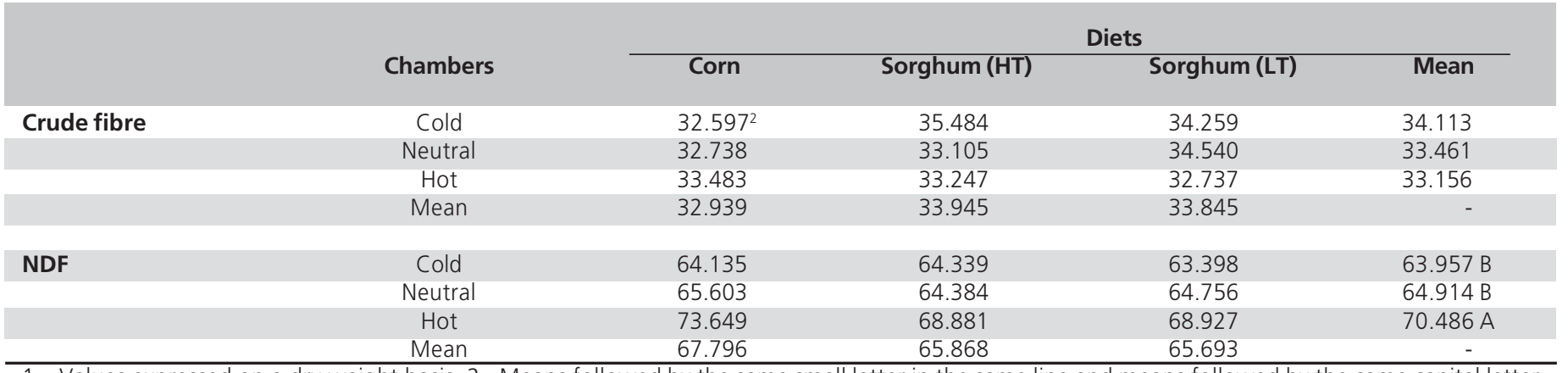

1 - Values expressed on a dry weight basis. 2 - Means followed by the same small letter in the same line and means followed by the same capital letter in the same column, do not differ according to Tukey's test $(p>0.05)$.

Table 4 - Digestibility coefficients 1 for acid detergent fibre (ADF) and ether extract determined by the digestibility assay using total excreta collection from broiler chickens fed on corn based, high tannin sorghum based (HT) and low tannin sorghum based (LT) diets and submitted to three room temperatures.

\begin{tabular}{|c|c|c|c|c|c|}
\hline & \multirow[b]{2}{*}{ Chambers } & \multicolumn{4}{|c|}{ Diets } \\
\hline & & Corn & Sorghum (HT) & Sorghum (LT) & Mean \\
\hline \multirow[t]{4}{*}{ ADF } & Cold & $27.982^{2}$ & 26.479 & 24.281 & 26.247 B \\
\hline & Neutral & 29.573 & 27.786 & 25.879 & $27.746 \mathrm{~B}$ \\
\hline & Hot & 35.394 & 33.482 & 36.815 & $38.564 \mathrm{~A}$ \\
\hline & Mean & $30.983 \mathrm{~A}$ & $29.249 A B$ & 28.992 B & - \\
\hline \multirow{4}{*}{ Ether extract } & Cold & 90.878 & 89.074 & 89.200 & 89.717 \\
\hline & Neutral & 91.445 & 89.362 & 90.592 & 90.466 \\
\hline & Hot & 91.615 & 90.217 & 91.367 & 91.067 \\
\hline & Mean & 91.313 & 89.551 & 90.386 & - \\
\hline
\end{tabular}

1 - Values expressed on a dry weight basis. 2 - Means followed by the same small letter in the same line and means followed by the same capital letter in the same column, do not differ according to Tukey's test ( $p>0.05$. 
Table 5 - Digestibility coefficients ${ }^{1}$ for mineral matter and nitrogen free extract (NFE), determined by the digestibility assay using total excreta collection from broiler chickens fed on corn based, high tannin sorghum based (HT) and low tannin sorghum based (LT) diets and submitted to three room temperatures.

\begin{tabular}{|c|c|c|c|c|c|}
\hline & \multirow[b]{2}{*}{ Chambers } & \multicolumn{4}{|c|}{ Diets } \\
\hline & & Corn & Sorghum (HT) & Sorghum (LT) & Mean \\
\hline \multirow[t]{4}{*}{ Mineral matter } & Cold & $63.288^{2}$ & 63.251 & 54.515 & $60.351 \mathrm{~B}$ \\
\hline & Neutral & 66.032 & 60.169 & 56.473 & $60.891 \mathrm{~B}$ \\
\hline & Hot & 73.919 & 66.011 & 63.821 & $67.917 \mathrm{~A}$ \\
\hline & Mean & $67.746 \mathrm{~A}$ & $63.144 \mathrm{AB}$ & $58.270 \mathrm{~B}$ & - \\
\hline \multirow[t]{4}{*}{ NFE } & Cold & 88.509 & 89.761 & 89.036 & $89.102 \mathrm{~B}$ \\
\hline & Neutral & 90.990 & 90.374 & 90.490 & $90.618 \mathrm{~B}$ \\
\hline & Hot & 93.057 & 92.512 & 93.626 & $93.065 \mathrm{~A}$ \\
\hline & Mean & 90.852 & 90.882 & 91.050 & - \\
\hline
\end{tabular}

1 - Values expressed on a dry weight basis. 2 - Means followed by the same small letter in the same line and means followed by the same capital letter in the same column, do not differ according to Tukey's test ( $p>0.05)$.

temperature and the greatest values for the acid detergent fibre digestibility coefficients were observed in the hot chamber. There was also a significant effect $(p<0.05)$ for the diets, the greatest digestibility coefficients being observed for the birds fed on the maize-based feed with results similar to those found by Mustafa \& El Zubeir (1993).

The digestibility coefficients for the nitrogen free extract only showed a significant effect $(p<0.05)$ for temperature, the greatest values for dry material being observed in the hot chamber.

In general temperature had a greater effect and the digestibility coefficients of the birds housed in the hot chamber were higher. These results agree with those of Gomes \& Macari (2000) who stated that feed consumption decreased under heat stress, the birds becoming lighter and drinking two or three times more water, increasing water excretion via panting and urinare, and increasing the digestibility of the nutrients in the diet.

\section{CONCLUSION}

Based on the results it was concluded that all the digestibility coefficients were higher in the birds housed in the hot chamber and lower in the cold chamber. The values also tended to be greater for the birds fed on corn.

\section{REFERENCES}

A.O.A.C.- Association Of Official Analytical Chemists. Official Methods Of Analysis. 15 ed. Arlington, Virginia, Washington, 1990. $1298 p$.
Bagepalli S, Rao N, Prabhavathi T. Tannin content of foods commomly consumed in India and its influence on ionizable iron. Journal of Food Science and Agriculture 1982; 33:89-96.

Chang MJ, Fuller HI. Dietary tannin from cowpeas and tea transiently alter apparent calcium absorption but not absorption of protein in rats. Journal of Nutrition 1993; 124:283-288.

Elkin RG, Featherston WR, Rogler JC. Condensed tannins are only partially responsible for variations in nutrient digestibilities of sorghum grain cultivars. Poultry Science 1995; 74 (Supplement 1): 125 (Abstract).

Gomes LFF, Macari M. Efeito do uso de enzimas sobre a digestibilidade de dieta a base de milho e farelo de trigo sob estresse térmico em frangos de corte colostomizados. In.: Conferência APINCO de Ciência e Tecnologia Avícola, 2000, Campinas, Anais...p.30.

Gualtieri M, Rapaccini S. Sorghum grain in poultry feeding. World's Poultry Science Journal 1990; 46:246-254.

Haslam E. Vegetable tannins. In: Conn EE. The biochemistry of plants, Vol. 7, Academic Press, New York, pp. 527-544, 1981.

Hill FW, Anderson DI. Comparison of metabolizable energy and productive energy determination with growing chicks. Journal of Nutrition 1958; 64:587-693.

Mahmood S, Smithard RA Comparasion of effects of body weight and feed intake on digestion in broiler cockerels with effects of tannins. British Journal of Nutrition 1993; 70:701-709.

Mehansho H, Butler LG, Carlson DM. Dietary tannins and salivary prolinerich proteins: interactions, induction and defence mechanisms. Animal Review of Nutrition 1987; 7:423-440.

Mitaru BN, Reichert RD, Blair R. Improvement of the nutritive value of hight tannin-sorghums for broiler chickens by hight moisture storage. Poultry Science 1984; 62:2065-2072. 
Mustafa EA, El Zubeir EA. Use of sorghum gluten feed as a substitute for soybean meal in diet for broiler chicks. World Animal Review 1993; 76:58-61.

Rostagno HS. Energia metabolizável do milho e do sorgo com diferentes conteúdos de tanino para aves. Revista Brasileira de Zootecnia 1977; 6(2):304-318.

Trevino J. Effects of tannin from faba beans (Vicia faba) on the digeston of starch by growing chicks. Animal Feed Science and Technology 1992; 37:345-349. 